AUTHOR(S) R. A. Martin

M. A. Merrigan

M. G. Elder

J. T. Sena

E. S. Keddy

C. C. Silverstein

SUBmitted to AIAA/SAR/ASME/ASEE Joint Propulsion Conference July $6-8,1992$

Nashville, TN

\title{
DISCLAIMER
}

This report was prepared an an account of work oponewred by an agency of the United Siates Oovernment. Neither the Unilod States (jovernmont nor any agency theroul, nor any of thair employees, makes any warranty. expreas or implied, of asumes any legal liabiluly or responaj. bility for the accuracy, cumpleteneas, or usefulness of any informaliun, upparatus, producl, of procesu disckmed, or represents thal ith use would not infringe privately uwned righin Refor. ome lierein to any apecific commercial producl, process, or service hy irude name, Iradeinart. manulaclures, of wherwime doen nok necensurily cunntilute or imply its endormement, recom.

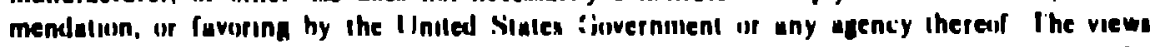

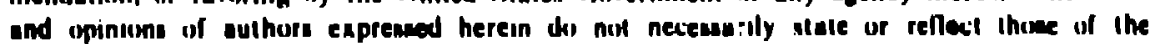
United Sitalen fiovernment or any agency theresf 


\section{ANA'YYTICAL AND EXPERIMENTAL STUDIES OF \\ HEAT PIPE RADIATION COOLING OF \\ HYPERSONIC PROPULSION SYSTEMS}

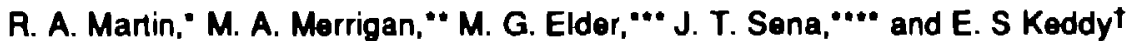 Los Alamos National Laboratory, Los Alamos, New Mexico}

and

C. C. Silverstein,

CCS Associates. Bethel Park, Pennsylvania

\section{Abstracl}

Preliminary, research-oriented, analytical and experimental studies were completed to assess the feasibility of using high-temperature heat pipes to cool hypersonic engine components. This now approach involves using heat pipes to transport heat away from the combustor, nozzla, or inlet regions, and to reject it to the environment by thermal radiation from an external heat pipe nacelle. For propulsion systems using heat pipe radiation cooling (HPRC), it is possible to continue to use hydrocarbon luels into the Mach 4 to Mach 6 speed range, thereby enhancing the economic sttractiveness of commercial or military hypersonic flight. In the second-phase feasibility program recently completed, we lound that heat louds produced by considering both convection and radiation heal translor Irom the combustion gas can be handled with HPRC design modifications. The application of thermal insulation to ramburnor and nozzlo walls was also found to reduce the heal load by about one-half and to reduce peak HPRC system temperatures to bolow $2700^{\circ} \mathrm{F}$. In addition, the operation of HPRC at cruise conditions of around Mach 4.5 and at an akitude of $90,000 \mathrm{H}$ lowers peak hol section temperatures to around $2800^{\circ} \mathrm{F}$. An HPRC heat pipe was successlully labricated and tested at Mach 5 conditions of hoal flux, heat load, and temperature.

\section{Backoround and Conceos}

For a long-range aircraft capable of laking off at sea level and climbing to hypersonic (above Mach 3) cruise conditions at up $10 \quad 100,000$ leol altifude, integraled, combined-cycle engines such as the lurbolanramjer are lavored over multiple engine types

\footnotetext{
'Grond MI I I Siah Momber. Momber AlaA

"Group Mr F 13 Depuly Group I ander

".Group Nit I 13 lochnician

-..'Group Mff 13 Slall Nombor

'Group MI I 13 I aboralory ABsocala

Iliresiden!

Ihie paper in declered a work ol ine IIS Ciuverinnent and is no eubject to copyrigtit proiecilon in the Unitud Siaton
}

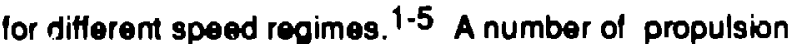
system ritical component tochnologies for such engines are ldentified. ${ }^{1}$ These technologies, including ongine cycle, cooling method, fuols, and materlals are being developed by private industry and the U.S. Government in programs such as High-Speed Propulsion Assessment (HiSPA) and High Mach Number Technology Engine (HiMaTE). ${ }^{6}$

HPRC is a newly proposed technique for passively cooling the hot secilon of a hypersonic engine, thus eliminating the need to use the engine fuel as the coolant. ${ }^{7-9}$ For an HPRC systom application at Mach 5 . the entire engine heat load, or about two-thirds of the total hypersonic alrcrait plus engine heat load, is removed from the hol section. This heat is transported by a surrounding, high-temperature, heat pipe nacelle structure to riearby external surfaces, and rojected to the environment by thermal radiation, as shown schomatically in Fig. 1.

HEAT PHPE RADIATOR CONCEPT:

TRANBVERSE TRANBPOAT - NACELLE BDE REJECTION

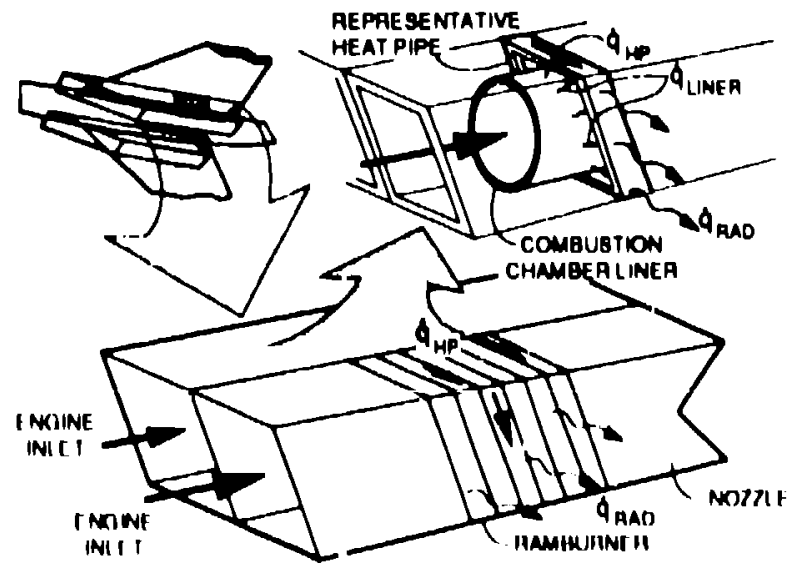

Fig. 1 HPRC concept

As indicated in Fig. 1, a portion of the engine nacelle consisls of buill-in heal pipe struclures designed to remove heal lrom belween the engines (or belween an engine and the wing or fuselage), ind to move this heat to a side. of bottom-facing surlace for repection to the environment by radiation heal lranslor 
In this configuration, the cylindrical ramburner and nozzle walls are labricated from special highloiriperature materials, such as (but not limited to) carbon-fiber-reinforced carbon matrix (carboncarbon $)^{10}$ or silicon-carbide-whisker-reinforced molybdenum disilicide matrix composites. 11 These walls receive heat from the combustion and exhaust gases by convection and radiation heat transfer and are allowed to achieve temperatures on the order of $2800^{\circ} \mathrm{F}$ or higher, depending on advances in the state of the art.

In Fig. 2 the ramburner and nozzle (hot section) are surrounded by a nacelle of square cross section, which is fabricated from filat heat pipe panels. The innerside, and bottom panels constitute one independent, L-shaped, conling subsystem, and the top and oute side panels constitute a second subsystem. Since the hot section is assumed to be part of a iwo-engine module that is mounted to the wing or fuselage underside, the interior side and upper heat pipe nacelle panols must be insulated. In a later section, this report will show that the HPRC test article consists of one scaled element from one of these $L$. shaped subsystems.
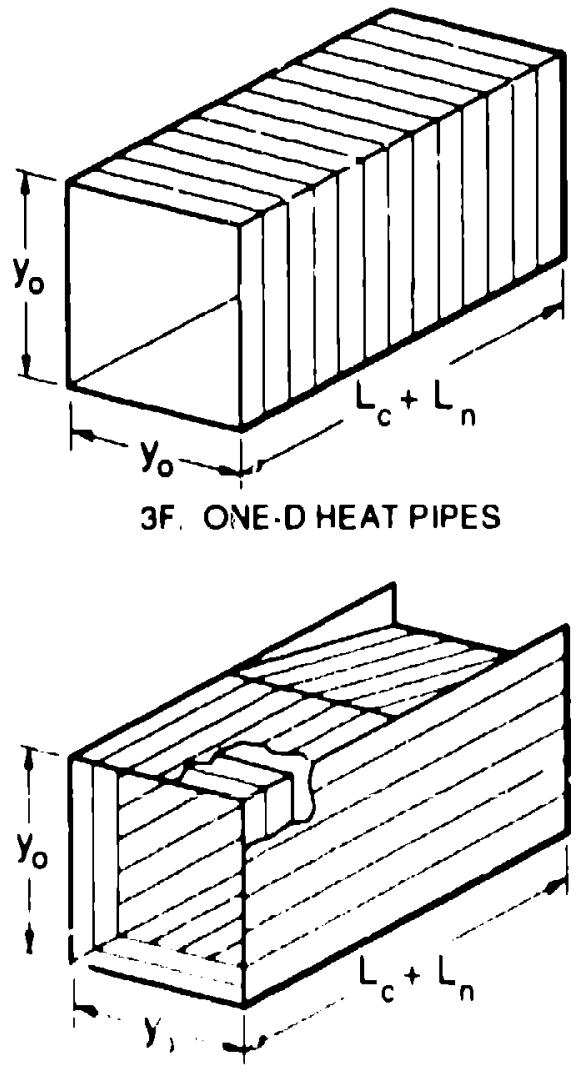

3V. ONE D HEAT PIPES

\section{F 2 ?wo HPAC configurations}

The ramburner and nozele walls radiate the engine heal load to the suriousing HIHAC portion of the nacolie, which transports the heal bad isothermally to side- or bottom-tacing heat pipe surtaces. These surfaces lose heat to the environment by convection and radiation heat transler at temperatures from $2100^{\circ} \mathrm{F}$ to $2400^{\circ} \mathrm{F}$. The required amount of heat pipe nacelle radiator exposed surface area will depend on the specifics of a particular propulsion system cooling design. Design options inclt te restricting the radiator, in length, to the ramburner plus nozzle region or extending it forward on the nacelle or outboard under the wing.

The remaining aircrat heat load, not accounted for by the HPRC system, is absorbed by JP-grade hydrocarbon (HC) fuel prior to combustion. Thus, HPRC is proposed as a cost-saving alternative, or complementary cooling technique, to the use of expensive, pumped cryogenic or endothermic fuels to provide regenerative fuel or air cooling of hot surtaces. By applying HPRC, the prolerred use of HC fuels is exiended into the Mach 4 to Mach 6 speed range.

An HPRC system is conceptually simple. It requires no pumping and operates at low pressure (around 10 psia). Also, because heat pipes operate nearly isothermally, thermal stresses are reduced, and engine structural designs are simplitied. High-strength materials and oxidation-resiztant coatings are used to fabricate the HPRC heal pipe nacelle, as well as the hot-section components. Hybrid thermal managoment systems using heat pipes combined with cryogenic of endothermic fuel cooling are possible.

\section{Previous Work}

The HPRC concept, the HPRC thermal analysis computer code, and results from the first (applications) phase of the HPRC program are described elsowhere. 7 . 8 During the applications phaso, information on ronfigurations, dimensions, temperatures, and cooling wads of hypersonic engines was oblained through discussions with personnel trom engine manufacturing companies.12-14 This information detines the representative engine.

Heat transter studies wore carried out during the applications phase to determine cooling system and hot-section temperatures, heat loads, and woights for the representative engine crulaing at Mach 5 at 80,000 It. The studies included cooling system requirements for both the ramjel combustor and nozzlu. A heat transter computor code was dovolopod to lacilitato these caculations. The capability of heat pipe internal fluid transport designs to meet HPRC cooling system heat transport requirements was assossed using results of Los Alamos heal pipe code. HTPIPE. ${ }^{15}$ Calculations.

In the previous applications phase, application of the HPAC concept resulted in reasonable sizes and woights, but at rolalively high material temperefures up to Mach 5 llight spoeds. These preliminary conceptual derign sludies suggested that the engine ramburner aris nozzle walls be labricoled from a material s uch as carbon carbon, which could operate at temperalures in oxcess of 3000"f. Howover, as shown in Ret 9 and in this paper, the ongine ramburner and nozzle wall 
lemperatures can operate at $2800^{\circ} \mathrm{F}$ or lower depending on cruise conditions and HPRC design specifics. This temperature is consistent with shortterm advanced high-lemperature materials goals.

Analytical and experımental results from the second (feasibility) phase of the HPQC pr. $: 1 \mathrm{~m}$ are reported here.

\section{Analytical Results}

At the high, uniform combustion gas recovery temperature of $4200^{\circ} \mathrm{F}$ assumed in this study, thermal radiation from the combustion gas is assumed to be a significant contributor to the gas-side suriace heat bad, along with convective heat transler. ${ }^{15}$ Only the convective heat transfer from the combustion gas to the ramburner and nozzle walls was considered in the applications phase. 7.8

In the present study. HiMaTE ramburner and nozzle liner gas-side surface heat llux data (including the effects of gas radiation) provided by GEAE were used to pertorm additional calculations with the HPRC thermal analysis code. ${ }^{9}$ Results of these calculations are summarized in Fig. 3 and compared with the original results, but not those that included gas radiation. In either case. the calculated ramburner and nozzle wall cemperatures exceod the ic 'el of about $2800^{\circ} \mathrm{F}$ currently available with high-temperature, composite materials coated with oxidation-resistant films. 10 Howevel, the development of high-strength materials that can wrihsland temperatures above ${ }^{7} 200^{\circ} \mathrm{F}$ is a key requirement for NASA-planned propulsion system advances. NASA and the engine companies believe that composite structural materials and oxidation protection coatings will bo avalable lor use in aircralt engines at such temperatures within the next 10 to 20 yoars. $17-18$

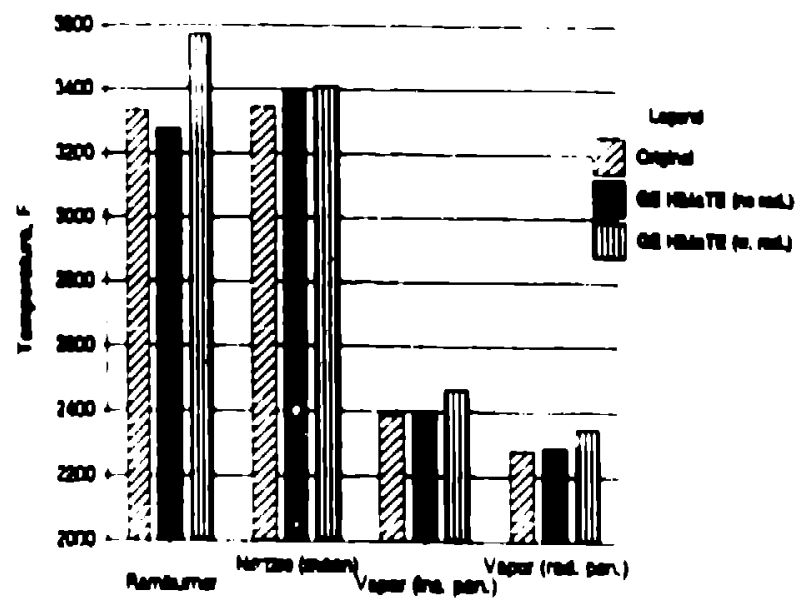

Fig. 3 HPRC system tomparaluies.

In addition. It necossary. IHPAC system and hol section temperaluies can ho kowared in ?800" of leas by using one of mote of the lollowing op' ons (1)
Increasing the size of the HPRC, : ating nacelle panels: (2) reducing the thickness of irie hot-section walls; (3) increasing the thermal conductivity of the hotsection walls; (4) adding a thermal" ating layer to the gas-side surlace of the hot se... Jn walls; (5) cruising at Mach 5 or less at an altitude doove $80.000 \mathrm{th}$ (lower dynamic oressure); or (6) cruisin f at a dynamic pressure of 1000 psf and a Mach number less inan Mach 5 (lower altitude). The effec:: if Options (4) Ihrough (6) are examined below.

One method lor reducing th:e hot-section temperalures of the originai HPRC sysiem design is to thermally insulate the hot-section walls, thcreby increasing the thermal resistance through the heat transter path. A heat transler calculation was pertormed using a thermal barrier coating (TBC) on the gas-side surface of the ramburner and nozzle walls. TBC consists of zirconia, partially stabilized with $8 \%$ wt yttria. TBC has been used with considerable effectiveness to reduce the heat load on internally cooled turbine vanes of jet engines. ${ }^{19}$ The thermal conductivity of this material is aboul $0.5 \mathrm{Btu} / \mathrm{h} \cdot \mathrm{tt} \cdot{ }^{\circ} \mathrm{F}$ at iemperatures 0 ! interest. 20 The effect of TBC is to increase the thermal resistance and reduce the thermal conductance at the combustion-gas hot-section wall intertace. It was assumed that a sufficient thickness of TBC would be added to the inner surface of the hot suction to reduce the thermal conductance $U$ in the ramburner to 30 Btu/t ${ }^{2} \cdot h \cdot{ }^{\circ} F$. The required thicknesses of TBC are then 0.130 in. on the combustor inner wall, and 0.108 in. on the nozzle inner wall. Using these thicknesses of TBC, the HPRC thermal analysis code was used to calculate the now system temperatures and woights summarized in Table 1 . Results from the previous applications phise calculations ${ }^{7-8}$ aru also shown in Table 1 lor comparison

As shown in Table 1, the addition of TBC reduced the heat load on the radiating panel by alinost one-half from $1214 \mathrm{Btu} / \mathrm{s}$ 10 $627 \mathrm{Blu} / \mathrm{g}$. This results in? substanlial reduction in iamperatures along the heat transle. path. The peak hot-section teniperature is now $2670^{\circ} \mathrm{F}$, whin noar-torm temperature goals tor carbuncarbon. Heat pipe temperatures, now in the $1900^{\circ}-$ range. run about $400^{\circ} \mathrm{F}$ cooler. Basud on a density $0.226 \mathrm{~m} / \mathrm{in}^{3}$ lor zirconia, 21 the princioal conatituent of TBC, 370 ib of fully dense TBC is required on the hotsection inner surface. The lrades in using TBC are the added weight of the TBC plus the need for the development of an effective thermally resistant bend between TBC and the liner wall material. 20

Resulis lrom the previous HPRC applications phase hral-iransler analyses $7-8$ were based on represe llative HiSPA engine data for a dvnamic pressure of $1000 \mathrm{lbMt}^{2}$, a llight spewd of Mach 5, and an allifude of $80,000 \mathrm{lt}$. The ettect of niher cruise conditions un HPRC system lemperatures was calculated 9 For the new cruise conejtions, new hot. section dimensions and new iniernal and exlernal heat. iransler coolficiunts were caiculated and input to the HPAC thermal analysis computer cude The maximum ramburner lemperalures resulting from theso

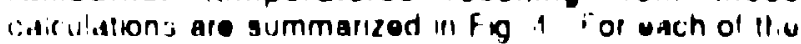


three Mach number cases in Fig. 4, the length of the HPRC nacelle is equal to the hot section length (112 in. at Mach 5, 104 in. at Mach 4.5, and 90 in. at Mach 4).

Table 1.

Calculations of Effect of TBC on HPRC Temperatures and Weight

\begin{tabular}{|l|c|c|}
\hline & Now & Previous \\
\hline $\begin{array}{l}\text { Combustor inner wall } \\
\text { temperalure, of }\end{array}$ & 2670 & 3345 \\
\hline $\begin{array}{l}\text { Nozzle inner wall } \\
\text { temperature, of }\end{array}$ & 2655 & 3362 \\
\hline $\begin{array}{l}\text { Heat pipe vapor } \\
\text { temperature-insulated } \\
\text { panel, of }\end{array}$ & 1964 & 2399 \\
\hline $\begin{array}{l}\text { Heat pipe vapor } \\
\text { lemperature-radiating } \\
\text { panel, of }\end{array}$ & 1910 & 2289 \\
\hline $\begin{array}{l}\text { Heat kad on insulated } \\
\text { panel, Btu/s }\end{array}$ & 270 & 521 \\
\hline $\begin{array}{l}\text { Heat load on transition } \\
\text { section, Biu/s }\end{array}$ & 351 & 670 \\
\hline $\begin{array}{l}\text { Heat load on radiating } \\
\text { panel, Btu/s }\end{array}$ & 627 & 1214 \\
\hline HPRC weight, lb & 630 & \\
\hline Weight of TBC, lb & 370 & \\
\hline Weight of HPRC + TBC, $\mathrm{b}$ & 1000 & \\
\hline
\end{tabular}

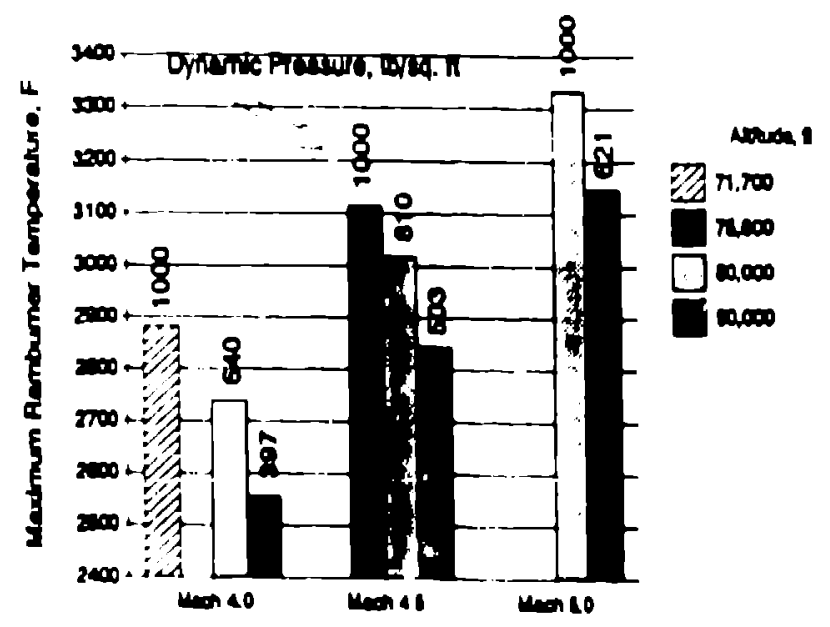

Fig. 4 EHects of attitud" and Mach number.

Fiom Fig. 4. It is ovident ihat the crulse Mach number and altitude have a slrong ellect on the maximum ramburner lemperature. For example, at Mach 5, the temperature diops trom 3320"F $103150^{\prime \prime} \mathrm{F}$ when the altilude incioases licm 80.900111090 .000 "l At Mach 45, the lomperature, at a dynamic pressure (q) of $10 \mathrm{CO} \mathrm{b} / \mathrm{tt}^{2}$ and an altitude of $-51505 \mathrm{H}$, drops 10 slightly over $3100^{\circ} \mathrm{F}$. As the altitude increases first 10 $80,000 \mathrm{ft}$ and then to $90,000 \mathrm{ft}$, the temnerature drops further, $103020^{\circ} \mathrm{F}$ and then $102860^{\circ} \mathrm{F}$. . M Mach 4.0, $\mathrm{q}=$ $1000 \mathrm{lb} / \mathrm{tt}^{2}$, and at an altitude of $71,7000 \mathrm{ft}$., the temperature is $2880^{\circ} \mathrm{F}$. As the altituce rises, first to $8(1,400 \mathrm{ft}$. and then to $90,000 \mathrm{H}$., the temperature drops to $2740^{\circ} \mathrm{F}$ and then to $2570^{\circ} \mathrm{F}$. These regults show that if the engine is cruising slightly be. . Mach 4.5 at $90,000 \mathrm{f}$., the hot-section temperature: will be around $2800^{\circ} \mathrm{F}$, a level within near-lerm expectations lor carbon-carbon. At Mach 4 and Mach 4.5, the maximum ramburner temperatures would be lower if the heat pipe nacelle length had been maintained at the reterence design value of 112 in.

\section{Exontimental Besulte}

HPRC nacolles consist of adjacent heat pipe elements, as illustrated in Figs. 1 and 2. A hoat pipe is a device that transters large amounts of heat through a small area with a small temperature difference and without external power or control. The principle of operation of a heat pipe is described in detail elsewhere.22-24 The lollowing procedures were used to optimize the HPRC hoat pipe for pertormance and weight: (1) identified ahornative wick structures and evaluated their relative pertormances, (2) selected and optimized one or more suitable wick structure(s), (3) designed heat pipus ior maximum thermal pertormance and minimunı weight, and (4) detailed and evalueted the performance of the solected design. Criteria for selecting and ovaluating alternative hoat pipo designs included woight and volume, epse of tabrication, and reliability. Design optimization was done on the basis of mass, power transport, and vapor temperature drops. ${ }^{7-}$

8 Thermal pertormance analyses were done by means of hand calculations and computer-aided calculations using HTPIPE. 15

In the feasibility phase the objective was to design a test article that could be used to demonstrate the principle of HPAC in the ground lest program. The test article configuration represents one element from one of two L-shaped cooling subsystem sections shown in Fig. 2 for a representative hyperwonic engine operating at cruise conditions at Mach 5 and 80,000 $\mathrm{H}$ altitude. This configuration was solected for the initial experiments on the basis of pertormance, operational, and labrication criteria. The test articie was scaled 10 demonstrate that the heat pipe nacelle can. in tact, operale at the design heat pipe temperature, provide adequate axial and radial heal transport capacty. and reject the required heal throughput by radiation heat transler.

Fipure 5 is a schematic drawing of the test article final conliguration. This test article was installed in the large vacuum chamber described in Rel. 9 and shown schomatically in Fig. 6 . A right-angle segmoni consisling of one slement of an HPAC heili pipe nacelle subsystem is shown. For the rdealized HPRC system of Fig. 2, a socond parallol right angle heal pipu is usod to Inrm a square box around the hyporsonic urging ramburner and nozzle such that the axes of the heal 
pipes are transverse (perpendicular) to the axis of the engine. For the representative engine, 112-in.-long ramburner plus nozzle system, the box incluJes 140 to 180 heat pipe tubes alor.g the engine axis, depending on the heat pipe cross-section design dimensions. For the leasibility phase test program, the overall length of the heat pipe was scaled to about 78 in. (two 39 in. legs). Figure 6 also shows that high-trequency, ifinduction coil heating was used to simulate heat input to the exte:ior surface of the heat pipe nacelle frum the hypersonic engine.

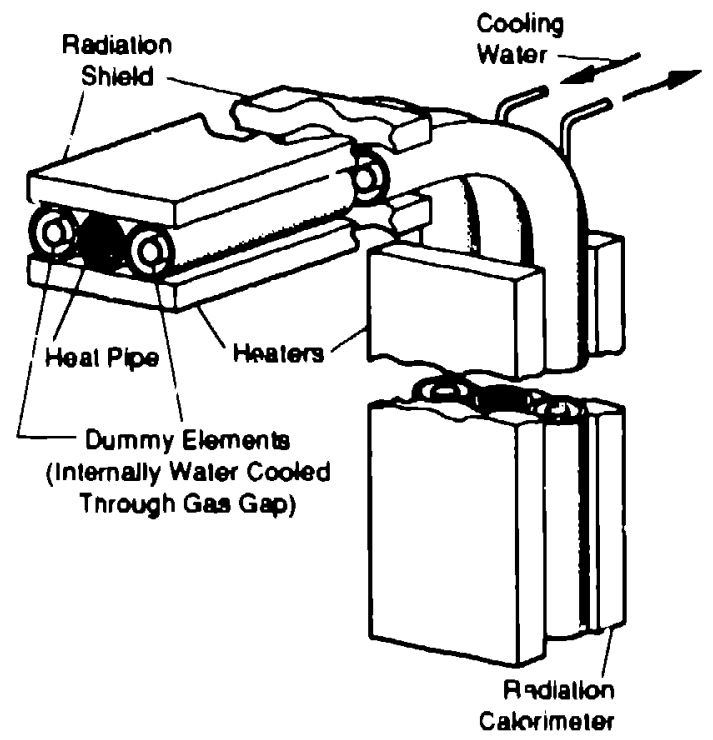

Fig. 5 HPRC lest anticle configuration

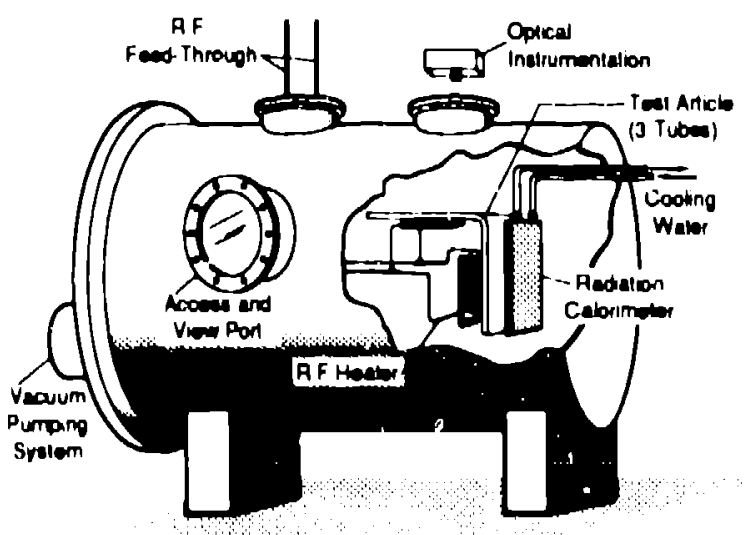

Fig. 6 HnRC tost lacility

The enclosure material chissen for the HPRC lest heal pipe was low-carbon arc-cast (LCAC) molybdenum. A riumber of lactors influenced the docision to use this matorial. The primaiy considetations were compa'ibility with the lithium viorking fluid, and consistency with HPRC applicalions phase requirements lor high temperalure capability and high strerigth Addilional considergtions included olecironbearn moldability, previous exporiance in working with this material at Los Alamos, cost, and availability.

A bias-wrap, annular wick design was used because bias wicks are more flexible than rigid sintered wicks and, therefore, bend more reliably. The bias-wrap labrication technique involved winding narrow strips of the wick material in a spiral lashion on a mandrel, while overlapping and spot welding the edges of the seam together. To prevent buckling of the wick in compression on the inner radius during the bending process, or during operation of the heat pipe, a spiralwound spring was inserted inside the wick. The wick was fabricated from $400-m e s h$ by $400-\mathrm{mesh}$ molybdenum (Mo)-41\% rhenium (Re)-alloy wire cloth. The completed wick satisfied an experimental pore check at an equivalent capillary radius of $37.5 \mathrm{~mm}$ with the spring installed.

The heal pipe handling, cleaning, bake-out (above $2400^{\circ} \mathrm{F}$ ), filling with $6 \mathrm{i} \mathrm{g}$ of pure lithium (by distillation at $1740^{\circ} \mathrm{F}$ ), and "wol-in" procedures are described in Rel. 9. Heat pipe fill calculations were pertormed to determine the required lithium charge mass. Enough lithium was desired to fill the heat pipe annulus and the wick screen material over the entire operating length of the wick, plus $15 \%$ overtill, based on previous experience. In addition, an 8-in.-length of extra tubing was required to handle the increase in specific volume of lithium when the lithium was heated to the operating temparature of $2240^{\circ} \mathrm{F}$

Reference 9 provides detailed descriptions of the apparatus and instrumentation used for wick development and testing, electron beam wolding, suppling $\mathrm{r}$-induction power, supporting and lilting the heal pipe, producing the vacuum, processing. distillation, filling, and tube bending.

Operational pertormance testing of the straight 86-in.-long HPRC heat pipe began on September 20, 1991. First tests were run with the heat pipe in a straight configuration to obtain proliminary data prior to bending 10 establish a perlormance (but not pertormance limits) baseline. These data were oblained to compare with pertormance data obtained later in the bent L.-shaped configuration because there was some risk of damage to the wick as a result of imposod stresses during the bending process. The heat pipe was installod inside a spocial vacuum lube mounted on a tith stand tor these proliminary lests.

Subsequently, a lotal of about $11 \mathrm{~h}$ of heat pipe operation was logged on the test article at HPFC design conditions, including both horizontal and lippod orientations. Heating was supplied by a spiral, 39-in. long. water-cooled, copper $\mathrm{H}$ coll. Tipped orientalions wers used to simulate the effect of gravitational head. Excellent performance was achieved. The heat pipe Iransported about $7.2 \mathrm{~kW}(6.8 \mathrm{Btu} / \mathrm{s})$ of power at the oporating temperalure of $1500 \mathrm{~K}\left(2240^{\circ} \mathrm{F}\right)$. This estimate is based on radiation from the entire 86-in.long heat pipo at an omissivity of 0.23 (moasurod al Los Alamos for clean, as-rocoived, molybdenum). The thermal power input of $7.2 \mathrm{~kW}$ corresponds to a radial hoat llux of $14.5 \mathrm{~W} / \mathrm{cm}^{2}$ (12.8 Btu/t $\left.{ }^{2} \mathrm{~s}\right)$, and an axial heat llux based on the vapor space (wick inside) diameler of $0.491 \mathrm{in}$. of $5.9 \mathrm{~kW} / \mathrm{cm}^{2}$ (5200 Blu/t ${ }^{2} \mathrm{~s}$ ) These numbers mool HPFC gystem thoorolical 
requirements based on applications phase calculations of 2475/2 = 1238 Btu/s total heat load for the ramburner plus nozzle, carried by one of two HPRC L-shaped nacelle systems consisting of 112 in./(0.625 in. per heat pipe) $=179$ adjacent heat pipes.

In additional tusting, the straight HPRC test article was run while tipped at an angle of $30^{\circ}$, with the evaporator section a: the top, showing a capacity to run with a 39-in. gravitational head. Further, the $30^{\circ}$ tipped heal pipe was shut down and successtully restarted from a cold condition, demonstrating a transient startup.

After these pertormance tests, the HPRC test article was successlully bent to an angle of $89^{\circ}$ using special retractory motal, tube-bonding apparalus. Prior to bending. the tube-bending apparatus and the mounted heat pipe were heated to a temperature in excess of $400^{\circ} \mathrm{C}\left(752^{\circ} \mathrm{F}\right)$ using an oxygen-acetylene torch in order to exceed the brittle-to-ductile transition temperature for the molyodenum enclosure tubing. which had spent about $8 \mathrm{~h}$ operating above its recrystalization temperature of about $1150^{\circ} \mathrm{C}\left(2100^{\circ} \mathrm{F}\right)$.

Final pertormance testing of the bent, L-shaped test anticle occurred in a large vacuum chamber during October 1991. A total of three tests of the bent HPRC heat pix were conducted in the large vacuum chamber The firsi two tests involved starting the heat pipe in a horizontal configuration (the two legs of the heat pipe formed a horizontal plane). The heat pipe started during the first test, but the test was terminated at a heat pipe surtace temperature of $1083^{\circ} \mathrm{C}$ 10 adjust the power output trim controls on the $\mathrm{A}$ generator. For the second test, the heat pipe was successlully started and brought up to operating temperature of $1224^{\circ} \mathrm{C}\left(2235^{\circ} \mathrm{F}\right)$ and hold lor ahout 5 minutes prior to shutting down.

Prior to the third bent HPFC heat pipe test, eight Type-K (chromol-alumel) thermocouples were fed into the vacuum tank vis vacuum.tight Conax teodthrough hardware and wore spol welded to the heat pipe from end-lo-end in soloclod locations. The heal pipe was installed in the vertical configuration (the hoated leg of the heat pipe was horizontal and the unheated leg was vertical) and $\mathrm{r}$-heated along 33 in. of the horizontal leg. About 2 hours into the test, a hot suot develuped about 6 to 8 in. tro:n the end of the horizontal leg, at a heat pipe surface lemperalure of $943^{\circ} \mathrm{C}\left(1730^{\circ} \mathrm{F}\right)$, and the heal pipe was shut down.

This vertical configuration posed the most sovere pertormance challenge to the heal pipo because in an actual HPRC application, the heat pipe will be heated over the entire active length. In an actual application, some of the working fluid vapor will muroly flow across the heated vertical leg and condense on the outer cool radiating surtace. Such fluid will then be wicked back to the other side of the heal pipe, rather than being transported against gravity back to the horizontal leg through the wick annulus. Future testing of the HPRC heal pips in the vertical configuration should include a more realistic distribution of the heat input.

\section{Concludino Romarks}

A now, research.orrented cooling concept is proposud lor cooling hypersonic aircrall propulsion systems. This HPRC concept is attractice, not because it provides more effective cooling than a fuelcooled engine, but because it shitts the burden of cooling to a passive radiation system. Corisequently. $\mathrm{HC}$ luels can be used at hypersonic speeds rather than specialized high thermal capacity fuels, which are much more expensive and require a completely new fuel supply and fuel handling inirastructure. Preliminary results of heat transfer, heat pipe, system, and experimental studies reveal that adequate heat transport capability is available using molybdenumlithium heat pipe technology. Analytical results show that the HPAC system radiator area can be limited in size to the ramburner-nozzle region of the engine nacelle; reasonable system woights are expected; hotsection temperatures are consistent with advanced structural materials' development goals for the next 10 1020 ye:

As srlown, radiation heat transfer from the not combustion gas can increase the heat load in the ramburner of a hypersonic engine. However, the extent of this increase and its impact on hot-section temperatures in an HPRC system require a more detailed thermal analysis than the approximate analysis described here. Higher heat loads that might result from taking gas radiation into account can be handled through suitable HPRC design moditications including increasing the size of heat rejection panels, using a thermal barrier coating, using thinner and/or higher thermal conductivity hot-section walls, and cruising al higher altitudes and/or lower Mach numbers.

The effucts of using thurmal barrier insulation on the interior walls of the ramburner and nozzle, and of cruising at lower Mach number and higher altitudes were investigated numarically. These conditions reduced hol-soction wall temperztures to $2800^{\circ} \mathrm{F}$ or bolow which is consistont with noar-torm juated carboncarbon temperature goals. Such temperatures are obtained either by insulating the liner wall with approximately $0.1 \mathrm{in.}$ if thermal barrier coating (TBC). or by cruising at abc'". Mach 4.5 at an atitude of 90,000 it. The adtition of TBC woule enable an increase in cruise Mach number and/or a decreaso in cruise altilude.

The results of experiunents reported herein demonstrate that HPRC heal pipes can be designed and tabricated, and that such heal pipos can provide the required hoal transport and thermal characteristics at the design basia conditions of Mach 5 and 80,000 ft. However, mush development work remains to be done to tiing the HPRC concepl to a state of lechnolojy roadingss.

\section{Acknowladamanis}

This work was pertormed under the auspices of tha Department of Energy and supported by the National Aeronaulics and Spare Adininistration, Lewis Research Center, through GSA Order Number C-30002. $M$. We are gratolul for the assistence of the technical staft at General Eloctric Aircraft Engines and United Technologias Prall arid Whitnoy. Mg. Carol Algiro prepared Ihis paper at Los Alamos. 


\section{Boforences}

1. Watts, J. D., ot al., "Mach 5 Cruise Aircraft Research." Langley Symposium on Aerodynamics, Vol. II, NASA Conterence Publicetion 2398, April 1985, pp. 285-304.

2. Kors, D. L., "Combined Cycle Propulsion for Hypersonic Flight, lAF-87263, 38th Congress of International Astronautical Federation, Brighton, United Kingdom, October 1987.

3. Anderson, (i. Y., Bencze, D. P., and Sanders, B. W., "Ground Tests Contirm the Promise of Hypersonic Propulsion," Aerospace Americe, Vol. 25, No. 9, Septomber 1987, pp. 38-42.

4. Kunkler, H. and Kuczera, H., "Turbo-Ramjet Propulsion System Concepts for Future European Space Transport (SANGER)," IAF-87-265, 38th Congress of the International Astronautical Federation, Brighton, United Kingdom, October 1987.

5. Tanatsugu, N. ot al., "Analytical Study of Spaco Plazo Powored by Air-Turbo Ramjot with Intake Cooler," IAF-87-264, 39th Congress of the International Astronautical Federatiofi, Brighton. United Kingdom, Octobor 1987.

6. Ahode, J. E., Overview of Hypersonic/ Transb!mospheric Vehicle Propulsion Tochnology. Aoropropulsion '91, NASA Conterence Publication 10063, 1991, pp. 6-1 to 6-11.

7. Martin, R. A., Koddy, M., Morrigan, M. A., and Sitverstoin, C. C. "Heat Pipe Radiation Cooling for High-Speed Aircralt Propulsion," Los Alamos National Laboratory report LA-UR-91-586. February 14, 1990.

8. Martin, R. A., Koddy, M., Merrigan, M. A., and Silvorstein, C. C., "Hoat Pipo Radiation Cooling of Advanced Hypersonic Propulsion System Components," AlAA F sper 91-2.358, June 1991.

9 Martin, R. A., Merrioan, M. A., Elder, M. G., Sena, J. T., Koddy, E. S., and Silverstoin, C. C., "Hoat Pipe Radiation Cooling lor High-Speed Aircralt Propulsion, Phase II Final report," Los Alamos National Laboratory Roporl in preparation.

10. Sheehan, J. E., "Oxidation-Resistant CarbonCarbon Composites," Engineered Materials Handbook. American Socioty for Melals International, Motals Park, OH, 1987, pp. 920921.

11. Cartar, D. H., "SiC Whisker-Pointorced MOSi2." Los Alamos National Laboratory report LA-11411. T, September 1988.
12. Hartsel, J. E., "High Speed Propulsion Assessment: HiSPA Program Summary.- General Eloctric Co., Cincinnati, OH, August 1988.

13. Hartsel, J. E., "High Speed Propulsion Assessmont: Customer Performance and Installation Data,- General Electric Co., Cincinnati, OH, 1987.

14. Glickstein, M. R., "High Spood Propulsion Assessment: Thermal Management Analysis," (United Technologies Pratt \& Whitney, W. Palm Boach, FL, Novomber 1986)

15. Woloshun, K. A., Morrigan, M. A., and Boat E. D., -HTPIPE: A Stoady-State Hea: Pipo Analysis Program, A User's Manual," Los Alamos National Leboratory Manual LA-11324-M, 1988.

16. Lelobvre, A. H., Gas Turbine Combustion, (Homisphere. Now York, 1983, Chapter 8).

17. Shaw, R. J., Overviow of Supersonic Cruise Propulsion Fesearch, Aoropropulsion '91, NASA Conference Publication 10063, 1991, p. 2-25.

18. Plencner, R. M. Knip, G. Jr., High-Etficiency Core Technology, Aeropropulsion '91, NASÁ Conferencu Publlcation 10063, 1991, pp. $32-1$ to 32-12.

19. Grisalfe, S. J. and Lowell, C. E., Overviow of Lowis Matorials Research - Contributions, Current Efforts, and Fulure Directions, Aeropropulsion 91, NASA Conterence Publication 10063, 1991, p. 23-8.

20. Strangmon, T. E. ot al., Thermal Barrier Ccating ilie - Prediction Model Dovelopment, Tubine Hot Section Technology 1987, NASA Conference Publication 2493, 1987, pp. 369-375.

21. Deane, C. W. System Sludy for Mach 5 Turboramjel Engines, Ropon No. A84-956687-10, United Technologies Rosearch Center, East Hartiord, CT. December 1984, p. 19.

22. Dunn, P. D. and Reay, D. A., Heat Pipes, 3rd od., (Pornammon Prosa Lid., 1982).

23. Chl, S. W., Hoal Pipo Thoory and Practlce: A Source Book, (Hemisphere Publishing Corporation, 1876).

24. Bronnan, P. J. and Kroliczek, E. J., "Heat Pipe Dosign Handbook," Vol. II, prepared by $B$ \& K Engineoring, Inc., lor NASA Goddard Space Flight Conter under contract no. NAS5-23406, $197 y$. 